\title{
IMPACT OF MODERNIZATION ON RELIGIOUS INSTITUTION: A CASE STUDY OF KHYBER PAKHTUN KHWA, PAKISTAN
}

\author{
Rashid MENHAS ${ }^{1}$, Shumaila UMER ${ }^{2}$, Saira AKHTAR ${ }^{3}$, Ghulam SHABBIR ${ }^{4}$ \\ ${ }^{1}$ Department of Sociology, Pir Mehr Ali Shah Arid Agriculture University, Rawalpindi, Pakistan \\ ${ }^{2}$ Department of Sociologv, Sardar Bahadur Khan Women University Ouetta, Pakistan \\ ${ }^{3}$ Department of Rural Sociologv. Universitv of Agriculture Faisalabad. Pakistan \\ ${ }^{4}$ Department of Sociology, Pir Mehr Ali Shah Arid Agriculture University, Rawalpindi, Pakistan \\ (C) 2015 Rashid Menhas, Shumaila Umer, Saira Akhtar, Ghulam Shabbir \\ This is an open access article distributed under the Creative Commons Attribution-NonCommercial-NoDerivs license \\ (http://creativecommons.org/licenses/by-nc-nd/3.0/) \\ DOI: 10.1515/eras-2015-0003
}

\begin{abstract}
Religion is a unified system of sacred norms, values, beliefs and objects. In any society religion plays an important role in the shaping of the people's lives, behaviour and interactions. In every aspect of life people consult with their religion and act according to the teachings of religion. At present modernization, globalization and social change are creating very drastic changes in every sphere of life. These changes have both negative and positive impacts on the society. Modernisation is also creating very serious changes in the social institution of religion. In Pakistan, modernization have very severe impact on religion and many sub-sects have been created under the religion of Islam. Each and every sect is claiming that their teachings are true. This phenomenon is crating sectarian violence in Pakistani society. Present study was conducted in the province of "Khyber Pakhtun Khwa, Pakistan". Pakhtun people follow religion strictly in every segment of life. They sacrifices their lives on the name of Islam. But at present due to modernization, this phenomenon has been changed. Main objective of this study was to analyze the major impacts of modernisation on the religion of Islam in "Pakhtun" culture and society.
\end{abstract}

Keywords: religion, impacts, modernization, sects, Pakhtun, Pakistan

\section{Introduction}

Modernization as a pattern of social change has influenced each aspect of life. Modernization has its early roots link with industrial revolution started in Great Britain in 17th and 18th century, and later on the process begun in America, France and japan. According to (Kornblum, 2002) the experience of industrialization, urbanization, and modernization are closely linked with each other and this process occurs simultaneously. The non-material aspects are marvelously explained by (Berger, 1977) in which he expressed views in terms of decline in small and traditional communities, the expansion of personal choice, increase in social diversity and awareness together with future orientation. Further the work of (Robertson ,1981), (Hawden,2005), (Simmel,1971),( Habermas ,1984) and (Kalogeraki,2009) support the idea of Berger in way that modernization is a source to create urban areas, importance of personal values, individualism, pluralism, heterogeneity, urbanization, extensive individual freedoms, loss of group control on individuals, commercialization etc. These all factors traces back to words of Germansociologist (Tonnies, 1937), who explained the turnout of society from Gemeinshaft (simple, homogenous, rural or traditional) to Gesselshaft (Complex, heterogeneous, Urban or modern) (Macionis, 2009). Here the uniting factors of traditional societies are erased and a new pattern of life emerges.

Religion is a power full force that affects the public and private life of an individual and groups through popular culture and social norms. In industrialised world changes comes very rapidly due to process of modernization. The world is tending now to more secular, rational and open to change in religious context (Granto, inglehart and leblang, 1996). A single traditional 
religion is no longer the central element of belief system. Cults, sects and secular values are vanishing religious principles (Robertson, 1981).

According to Tonnies and Durkheim, industrialization weakens traditions. Shortly, modern society turns away from gods. Weber studied capitalist, the scientist and the bureaucrats and approved the upper statements. He concluded that organizational workers move away from the questions of meaning and purpose of human existence (Macionis, 2009).

Islam is a religion, which brings mission of liberation and salvation. It is a teachings deriving from God and oriented towards humanity. Islam reacts towards modernity in two direction: the reformists/modernists and the fundamentalists. Reformists apply their mission in threefold: first, to define Islam by bringing out the fundamentalists in rational and liberal manner; second, to emphasis among others, the basic ideals of brotherhood, tolerance, and social justice; and third, to interpret the teachings of Islam in such a dynamic character in the context of the intellectual and scientific progress of modern world (Hussain, 1995).

\section{Statement of the Problem}

Pakhtun's have their own complete code of life. They have their own unique kind of social structure including major social institutions and their own way of life known in the form of a culture. As modernization is a universal process and affect each and every aspect of society wither developed or underdeveloped. The impacts may be positive or negative but the main concern this research is on negative impacts of modernization which bring social disorganization in Pakhtun social structure and Pakhtun code of life. Modernization influences the structure and functions of Pakhtun social institutions.From one side modernization looks like a sign of economic growth, industrialization, modern civilization; they are the engine room of economic growth and the centers of culture, entertainment, innovation, education, knowledge, and political power, social change, social growth, globalization, liberalization, internationalization, commercialization, transportation, communication, social mobility and social development, but from the other side it is a disaster to culture. Due to modernization the cultural identity became vanished, changed and mixtures, the life became complex, also change in language, dress, symbols, traditions, family, religious beliefs, and behavior occurs. Political instability, crime ratio increasing day by day, unemployment, frustration, difficulties in mobility, sectarianism, pollution, health problems, drug addiction, child labor, lack of cooperation and solidarity, change in family pattern and structure that is joint family become nuclear family, changes political institution, change the attitude of people, mode of living it means modernisation effected all the social institutions that is education, economic, family, political, religious, and recreational institution.), social process, social organization as a whole.

\section{The Significance of the Study}

This study is an important source of knowledge in the field of modernization theory with special regards to Pakhtun social structure. The study will increase the knowledge in terms of Pakhtun culture and the changes in it due to process of modernisation. In same context, it is a source to redirect the attitude of Pakhtun's towards the modernization process.with special regards to Pakhtun social structure. The study will increase the knowledge in terms of Pakhtun culture and the changes in it due to process of modernisation. In same context, it is a source to redirect the attitude of Pakhtun's towards the modernization process.

\section{Review of Literature}

Robertson (1981) said that until a few centuries ago, the human population of the world consisted of a large number of relatively localized and isolated societies, most of whose members lived at a subsistence level in economies based on hunting, gathering, horticulture, pastoralist, or agriculture. The industrial revolution ushered in an entirely new type of society, one that produced unprecedented wealth but also undermined or destroyed traditional forms of social organization and created new ones in their place. The modernization process in the early industrial societies of Europe took several generations. In these countries, culture and social 
structure were able to adapt relatively slowly, although not necessarily very easily, to the social changes involved.

Kornblum (2002) argued major source of social change is the set of trends that are collectively known as modernization. This term encompasses all the changes that societies and individuals experience as a result of industrialization, urbanization, and the development of nation states. These processes occurred during a period of two or more centuries in western nations Japan, but they are taking place at a far more rapid rate in the former colonial societies that are today's new nations.

Weber (1978) said that modernity means replacing a traditional worldview with a rational way of thinking. In preindustrial societies, traditions act as constant brake on change. To traditional people, "truth" is roughly the same as "what always been". To modern people, however, "truth" is the result of rational calculation. Because they value efficiency and have little reverence for the past, modern people adopt whatever social patterns allow them to achieve their goals.

Berger (1977) said that in preindustrial societies, strong family ties and powerful religious beliefs enforce conformity and discourage diversity and change. Modernization promotes a more rational, scientific, worldview as tradition loses its hold and people gain more and more individual choice. The growth of cities, the expansion of impersonal bureaucracy, and the social mix of people from various backgrounds combine to foster diverse beliefs and behavior.

\section{Methodology}

Research methodology is a set of explicit rules and regulations on which the foundation of research is laid down (Nichmias \& Nichmias, 1992). The major objective of methodology is to explain various tools and techniques employed for the collection, analysis and interpretation of data related to research problem under investigation.

\section{Sampling Technique}

Sampling is a statistical process in which subsets from the target population select to achieve the study objectives. In the present study, a sample of 60 students from University of Peshawar was taken through stratified random sampling.

\section{Tools of Data Collection}

A well-designed questionnaire was used for the data collection from the respondents. The questionnaire was based upon close ended and open-ended questions.

\section{Pre-Testing}

Before the collection of the data, five questionnaire was pre-tested the irrelevant and confused questions were excluded from questionnaire.

\section{Analysis of the Data}

Data analysis was carried out through SPSS (Statistical Package for Social Sciences) and the data is presented in frequencies, averages and percentage along with a detailed discussion on each table.

\section{Results and Discussions}

Analysis of the data and interpretation of results is the vital feature of the scientific research. Without analysis and interpretation of the data, generalization and prediction cannot be made, which is the goal of the scientific research. Generalization andconclusion are drawn on the basis of characteristics andattitudes of the respondents. 
Table 1. Modernization and Religious Institution

\begin{tabular}{lccc}
\hline Statements & Frequency & Percent & Cumulative Percent \\
\hline Modernization has no impacts religious institution & 6 & 10.0 & 10.0 \\
The percentage of offering prayers is on decline & 14 & 23.3 & 33.3 \\
It declines religious attendance and gatherings & 20 & 33.3 & 66.7 \\
Reduction in recitation of religious books & 10 & 16.7 & 83.3 \\
Traditional religious practices have been affected & 10 & 16.7 & 100.0 \\
\hline Total & $\mathbf{6 0}$ & $\mathbf{1 0 0 . 0}$ & \\
\hline
\end{tabular}

Table 1 shows that $10 \%$ of the respondents were of the opinion that modernisation have no impacts on religious institution while $90 \%$ favored that modernization has impacts on religious institution. About $23.3 \%$ said that modernization declines the percentage of offering the prayers while $33.3 \%$ argued that it declines the religious attendance and gatherings. Modernization leads to reduction in recitation of religious books, the statement was supported by $16.7 \%$ respondents while $16.7 \%$ stated that modernization affects traditional religious practices as (Davie, 1994) said that the condition in decline of religious practice is because of modernization.

Table 2. Modernization and Religious Festivals

\begin{tabular}{lccc}
\hline Statements & Frequency & Percent & Cumulative Percent \\
\hline Modernization does not influence religious festivals & 17 & 28.3 & 28.3 \\
Decline in the observance of local festivals & 30 & 50.0 & 78.3 \\
More tendency to Valentine & 5 & 8.3 & 86.7 \\
$\begin{array}{l}\text { Due to individualism people do not tends towards such } \\
\text { gatherings }\end{array}$ & 8 & 13.3 & 100.0 \\
\hline Total & $\mathbf{6 0}$ & $\mathbf{1 0 0 . 0}$ \\
\hline
\end{tabular}

Table 2 depicts that $28.3 \%$ of the respondents stated that modernization does not influence religious festivals and 50\% argued that modernization causes decline in the observance of local festivals as (Reed, 2010) argues that modernization is one of the source on of decline religious practices. About $8.3 \%$ supports that there is more tendency towards Valentines due to modernisation while $13.3 \%$ of the respondents were of the opinion that modernization causes individualism due to which people do not tends towards such gatherings.

Table 3. Modernization and Secularization

\begin{tabular}{lccc}
\hline Statements & Frequency & Percent & Cumulative Percent \\
\hline Modernization does not leads to Secularization & 18 & 30.0 & 30.0 \\
Decrease in religious hold & 10 & 16.7 & 46.7 \\
Increase in crime ratio & 9 & 15.0 & 61.7 \\
Individualism & 11 & 18.3 & 80.0 \\
Increase in psychological issues & 5 & 8.3 & 88.3 \\
Loss of faith and belief & 7 & 11.7 & 100.0 \\
\hline Total & $\mathbf{6 0}$ & $\mathbf{1 0 0 . 0}$ & \\
\hline
\end{tabular}

Table 3 reveals that $30 \%$ of the respondents were of the opinion that modernization does not leads to secularization while $70 \%$ answered in favor as (Robertson,1981) said that modernization causes secularization which results in leaving religion as marginal social institution. Then further in explaining it through indicators $16.7 \%$ argued that modernization leads to secularization resulting in decrease of religious hold and modernity have weakened the hold of religion in society. Increase in crime due secularization was supported by $15 \%$ respondents. About $18.3 \%$ of the respondents stated that it is a source of individualism while $8.3 \%$ of the respondents were of the opinion that secularization is the source to create psychological problems and $11.7 \%$ of the respondents supported that it leads to loss of faith and 
belief which is supported by Davie (1994), suggesting that decline in religious practices and secularisation is conditions of modernity and may indicate decline in religious beliefs.

Table 4. Modernization and Norms and Values of Islam

\begin{tabular}{lccc}
\hline Statements & Frequency & Percent & Cumulative Percent \\
\hline Modernization does not affect the norms and values of Islam & 8 & 13.3 & 13.3 \\
It disturbs the Purdah system in Islam & 30 & 50.0 & 63.3 \\
Less respect of elders & 10 & 16.7 & 80.0 \\
It declines female modesty & 12 & 20.0 & 100.0 \\
\hline Total & $\mathbf{6 0}$ & $\mathbf{1 0 0 . 0}$ & \\
\hline
\end{tabular}

Table 4 shows that about $13.3 \%$ s respondents said that modernization does not influence norms and values of Islam while $86.7 \%$ argued that modernization influence the norms and values of Islam. About 50\% argued that modernization disturbs the Purdah system in Islam as (Habermas, 1984) that decline in Purdah is one of the prominent characteristics of modernising sub-continent after 1970. About $16.7 \%$ support that modernization reduces respect of elders while $20 \%$ stated that it declines female modesty.

Table 5. Modernization and Sectarianism

\begin{tabular}{lccc}
\hline Statements & Frequency & Percent & Cumulative Percent \\
\hline Modernization does not produce sects in Islam & 23 & 38.3 & 38.3 \\
Sectarianism creates internal conflicts among Muslims & 7 & 11.7 & 50.0 \\
Sectarianism vanishes unity among Muslims & 10 & 16.7 & 66.7 \\
It presents negative projection of Islam to Non-Muslims & 10 & 16.7 & 83.3 \\
Sectarianism provides more chance for external interference & 3 & 5.0 & 88.3 \\
It leads to lack of tolerance & 7 & 11.7 & 100.0 \\
Total & $\mathbf{6 0}$ & $\mathbf{1 0 0 . 0}$ & \\
\hline
\end{tabular}

Table 5 shows that about $38.3 \%$ of the respondents viewed that modernization does not produce sects in Islam while $61.7 \%$ agreed as Robertson (1981) said that a single traditional religion is no longer the central element in a society's belief system. Cults, sects, and denomination multiply and increasing numbers of people interpret the world through secular rather than religious principles. Further $11.7 \%$ of the agreed respondents stated sectarianism creates internal conflicts among Muslims as Moaddel (2002) said that the cause of internal conflict among Muslims is modern religious and political sects. $16.7 \%$ argued that sectarianismvanishesunity among Muslims. It presents negative projections of Islam to nonMuslims; the statement was supported by $16 \% .5 \%$ respondent's supported that sectarianism provides more chances for external interference while $11.7 \%$ of the respondents were of the opinion that it leads to lack of tolerance.

\section{Conclusions}

Modernization causes decrease in percentage of offering prayers, reduction in recitation of religious books and declined in religious practices. Modernizations affect the religious festivals which further leads to tendency towards valentine and individualism. Modernization is a source towards secularization which decreases religious hold, causes individualism, psychological problems and loss of faith and belief. It is extracted that modernisation affects the norms and values of Islam and is specified that it disturbs the Purdah system, female modesty and loss of respect of elders. Another important concept in Islam is the creation of sects now a day. Regarding this phenomena it is concluded that modernization create sects in Islam which is responsible for internal conflict among Muslims, negative projection of Islam to non-Muslims, chance for external interference and lack of tolerance. 


\section{References}

Berger, P.L (1977). Facing up the modernity: Execution in society, politics and religion. New York basic books.

Davie, D. (1994). Outward-Oriented Developing Economies Really Do Grow More Rapidly: Evidence from 95 LDCs, 1976-1985. Economic Development and Cultural Change 13: 523-44.

Granato, J. Inglehart, R, and Leblang, D. (1996). The Effect of Cultural Values on Economic Development: Theory, Hypotheses, and Some Empirical Tests. American Journal of Political Science, 40, 3; 607-618.

Habermas, J. (1984). The theory of communicative action. Life world and system: A critique of functionalist reason, Boston: Beacon Press.

Hawdon, J. (2005). Drug and alcohol consumption as functions of social structures; a cross-cultural sociology, Lewistown, N.Y.: Mellen Press.

Husain, Z. (1995).Global Islamic Politic, New York: HarperCollins College Publishers. pp. 95.

Kalogeraki, S. (2009). The Divergence Hypothesis in Modernisation Theory Across Three European Countries: the UK, Sweden and Greece. Culture Unbound Journal of Current Researches, Volume 1, 2009: 161-178. Hosted by Linköping University Electronic Press: http://www.cultureunbound.ep.liu.se; 164.

Kornblum, W. (2003). Sociology in a changing world.Wadsworth/Thomson Learning 10 Davis Drive Belmont, CA 94002-3098 USA.

Macionis, J, J (2009). Sociology, Dorling Kindersley (India) Pvt. Ltd.; 629.

Moaddel, M. (2002). The Study of Islamic Culture and Politics: An Overview and Assessment, Annual Review of Sociology (28); 359-86.

Nachmias, C. F. and D. Nachmias. (1992). Research methods in social sciences. Fourth Edition St. Martin's Press; 14.

Naz, A. and Khan, W. (2011). University Annual Report. University of Malakand Press.

Reed, R.S, (2010). Analyzing Secularisation and Religiosity in Asia, Faculty of Policy Studies Chuo University Tokyo, Japan.

Robertson, I. (1981). Sociology, Worth Publishers, Inc.444 Park Avenue South New Yorkn10016, 613-616.

Simmel, G. (1971). Group expansion and the development of individuality, in D.N. Levine (ed): On Individuality and Social Forms, Chicago: University of Chicago Press, 251-293.

Tonnies, F. (1937); orig, (1987). Community and society (Gemeinshaft and Gesselshaft). New York: Harper and Row.

Weber, M (1978, orig; 1921). Economy and Society. G. Roth and C. Wittich, eds. Berkeley: University of California Press. 